\title{
Delayed seroconversion to STLV-1 infection is associated with mutations in the pol and rex genes
}

\author{
Syamalima Dube, Nitin Saksena², Timothy Spicer ${ }^{1}$, Jayne Healey ${ }^{1}$ Patricia Benz ${ }^{1}$, Dipak K Dube \\ and Bernard J Poiesz ${ }^{1 *}$
}

\begin{abstract}
Background: Simian T-cell lymphoma/leukemia virus-1 (STLV-1) infection of non-human primates can serve as a model for human T-cell lymphoma/leukemia virus infection.

Methods: Two tantalus and 2 patas monkeys were transfused with intraspecies whole blood infected with STLV-1. Infection was determined by ELISA, western blot and DNA PCR analyses. The entire genome of the STLV-1 Tan 90 strain and some of the STVL-1 Pat74 strain were amplified using over-lapping primer-pairs and subsequently sequenced.

Results: Followup studies conducted over 2 years indicated that all 4 monkeys remained healthy despite being infected with STLV-1, as determined by PCR, cloning and sequencing analyses. ELISA and Western blot analyses indicated that both patas monkeys seroconverted within 2 months of transfusion, while one tantalus monkey required one year to seroconvert and the other never fully seroconverted. The tantalus monkey which never fully seroconverted, failed to react to HTLV-1 p24 Gag antigen. Sequence analyses indicated that, while unique, the deduced p24 Gag amino acid sequence of the STLV-1 Tan 90 strain used for infection was still highly homologous to the HTLV-1 p24 Gag amino acids present in the ELISA and WB assays. However, a mutation in the pol sequence of STLV-1 Tan 90 encoded a putative stop codon, while a common deletion in the pol/rex regulatory gene causes significant changes in the Pol, and p27 Rex proteins. These same mutations were also observed in the viral DNA of both recipient infected tantalus monkeys and were not present in the STLV-1 Pat 74 strain.
\end{abstract}

Conclusion: Our data suggest that seroconversion to STLV-1 infection may be prolonged due to the above mutations, and that compensatory molecular events must have occurred to allow for virus transmission.

\section{Introduction}

The primate T-cell lymphoma/leukemia viruses (PTLV) are comprised of at least four, and possibly six, distinct species that infect both simians (STLV) and/or humans (HTLV) [1,2]. Relative to other primate retroviruses (e.g. HIV, SIV), PTLV transmission is often characterized by slow or indeterminate seroconversion [3,4]. HTLV-1 is associated with a variety of clinical disorders including T-cell lymphomas and leukemias, neurodegenerative disease, polymyositis, arthritis and uveitis [5]. STLV-1

\footnotetext{
* Correspondence: poieszb@upstate.edu

'Division of Hematology/Oncology, Department of Medicine, State University of New York, Upstate Medical University, 750 East Adams Street, Syracuse, NY 13210, USA

Full list of author information is available at the end of the article
}

has also been shown to cause T-cell lymphomas and leukemias [6-8]. Hence, STLV-1 infection of non-human primates could serve as a model for human PTLV infection, seroconversion, and disease pathogenesis.

In the past, we described that STLV-I infection was endemic among Chlorocebus (African green monkeys) and Erythrocebus patas (African red monkeys) in Central African Republic [9,10]. Two unique strains, STLV-1 Tan 90 and STLV-1 Pat 74 from a Chlorocebus tantalus and a Erthrocebus patas, respectively, were identified. These strains diverge from the prototype Japanese HTLV-I (ATK) isolate by $7.1 \%$ and $5 \%$, respectively, and from each other by $9.3 \%$. Herein, we describe experimental intraspecies transmission of these two strains resulting in varied seroconversion patterns. An extensive sequence analysis

\section{Biomed Central}


was conducted on both strains to seek an explanation(s) for the observed differences in seroconversion.

\section{Results}

During the entire two year observation period all three tantalus and three patas monkeys remained healthy. Their complete blood counts, CD4 and CD8 counts remained stable and within normal limits (data not shown). None of the animals developed clinical signs of a PTLV- associated disease.

The serological and PCR analyses on the tantalus and patas monkeys transfused with whole blood from Tan 90 and Pat 74, are shown in Table 1 . As can be seen, following transfusion, all monkeys were ultimately shown to be infected by PCR analyses for the STLV-1 pol and $p X$ genes (Table 1). Sequence analyses of the amplified DNA indicated that the tantalus and patas monkeys were infected with the STLV-I isolates that they had been inoculated with; i.e. STLV-1 Tan90 and STLV-1 Pat 74 , respectively (Figure 1 ).
Interestingly, while the patas monkeys had fully seroconverted by 2 months post-transfusion, both tantalus monkeys displayed prolonged seroconversion patterns. Both Tan 95 and Tan 97 took a year to become ELISA positive, and Tan 95 was still Western blot indeterminate at $2 \mathrm{yr}$ post transfusion, never reacting to the Gag p24 protein (Table 1, Figure 2). In addition, the intensity of the WB reactivities of Tan 95 serum was much less than that of the sera from the other monkeys. Because STLV-1 Tan 90 is a relatively divergent African STLV-1 isolate, it was plausible that its p24 gag gene might be defective or that its cognate protein might be quite different from the Japanese HTLV-1 p24 antigen utilized in the Western blot [9-11]. Hence, we amplified, cloned and sequenced the p24 gag gene of STLV-1 Tan 90 (Figure 3). As can be seen, there are only minimal amino acid changes in the Tan 90 isolate relative to other PTLV-1 isolates.

In addition to their slower seroconversion to STLV-1, the target tantalus monkeys took longer than the patas

Table 1 Chronology of serological (ELISA \& WB) and PCR analyses of monkeys experimentally infected with STLV-1 Tan 90 or STLV-1 Pat 74

\begin{tabular}{|c|c|c|c|c|c|c|c|c|c|c|c|c|c|c|c|c|}
\hline \multirow{2}{*}{$\begin{array}{l}\text { Target } \\
\text { monkey }\end{array}$} & \multirow[t]{2}{*}{ SIV } & \multirow[t]{2}{*}{ Inoculumn } & \multirow{2}{*}{$\begin{array}{c}\text { Months } \\
\text { post } \\
\text { exposure }\end{array}$} & \multirow[t]{2}{*}{ ELISA } & \multicolumn{12}{|c|}{ WB } \\
\hline & & & & & Status * & rgp21 & p19 & p24 & p26 & p28 & p32 & p36 & gp46 & p55 & rgp46 & $\mathrm{PCR}^{\boldsymbol{\Lambda}}$ \\
\hline \multirow[t]{6}{*}{ Tan 95} & + & STLV-1 Tan 90 & 0 & - & - & - & - & - & - & - & - & - & - & - & - & - \\
\hline & & & 2 & - & - & - & - & - & - & - & - & - & - & - & - & - \\
\hline & & & 4 & - & - & - & - & - & - & - & - & - & - & - & - & + \\
\hline & & & 11 & - & I & - & ++ & - & + & + & - & + & - & - & - & + \\
\hline & & & 12 & + & I & + & ++ & - & + & + & + & + & - & + & +++ & + \\
\hline & & & 24 & + & 1 & + & ++ & - & + & + & + & + & - & + & +++ & + \\
\hline \multirow[t]{6}{*}{ Tan 97} & - & STLV-1 Tan 90 & 0 & - & - & - & - & - & - & - & - & - & - & - & - & - \\
\hline & & & 2 & - & - & - & - & - & - & - & - & - & - & - & - & - \\
\hline & & & 4 & - & - & - & - & - & - & - & - & - & - & - & - & + \\
\hline & & & 11 & - & + & + & +++ & +++ & ++ & +++ & + & ++ & + & + & + & + \\
\hline & & & 12 & + & + & +++ & ++++ & ++++ & ++++ & ++++ & ++++ & ++++ & + & + & +++ & + \\
\hline & & & 24 & + & + & +++ & ++++ & ++++ & ++++ & ++++ & ++++ & ++++ & + & + & +++ & + \\
\hline \multirow[t]{5}{*}{ Pat 73} & - & STLV-1 Pat 74 & 0 & - & - & - & - & - & - & - & - & - & - & - & - & - \\
\hline & & & 2 & + & + & + & +++ & ++ & +++ & ++ & ++ & ++ & + & + & + & + \\
\hline & & & 4 & + & + & + & +++ & ++ & ++++ & ++++ & ++++ & ++++ & + & + & +++ & + \\
\hline & & & 5 & + & + & ++ & ++++ & ++++ & ++++ & ++++ & ++++ & ++++ & + & + & +++ & + \\
\hline & & & 16 & + & + & ++ & ++++ & ++++ & ++++ & ++++ & ++++ & ++++ & + & + & ++++ & + \\
\hline \multirow[t]{5}{*}{ Patt } & - & STLV-1 Pat 74 & 0 & - & - & - & - & - & - & - & - & - & - & - & - & - \\
\hline & & & 2 & + & + & + & +++ & + & ++ & +++ & ++ & ++ & + & + & + & + \\
\hline & & & 4 & + & + & +++ & ++++ & ++++ & ++++ & ++++ & ++++ & ++++ & + & + & +++ & + \\
\hline & & & 5 & + & + & +++ & ++++ & ++++ & ++++ & ++++ & ++++ & ++++ & + & + & +++ & + \\
\hline & & & 16 & + & + & +++ & ++++ & ++++ & ++++ & ++++ & ++++ & ++++ & + & + & ++++ & + \\
\hline
\end{tabular}

* WB status $=+$ if reactivity to both Gag p24 and Env gp46 original were observed, I+ indeterminate, and - if no reactivity at all. The intensity of the WB was rated as ranging from negative $(-)$ to $4+$.

$\Delta$ PCR was performed for both pol and pX genes. All + samples were + for both, and all - samples were - for both. 


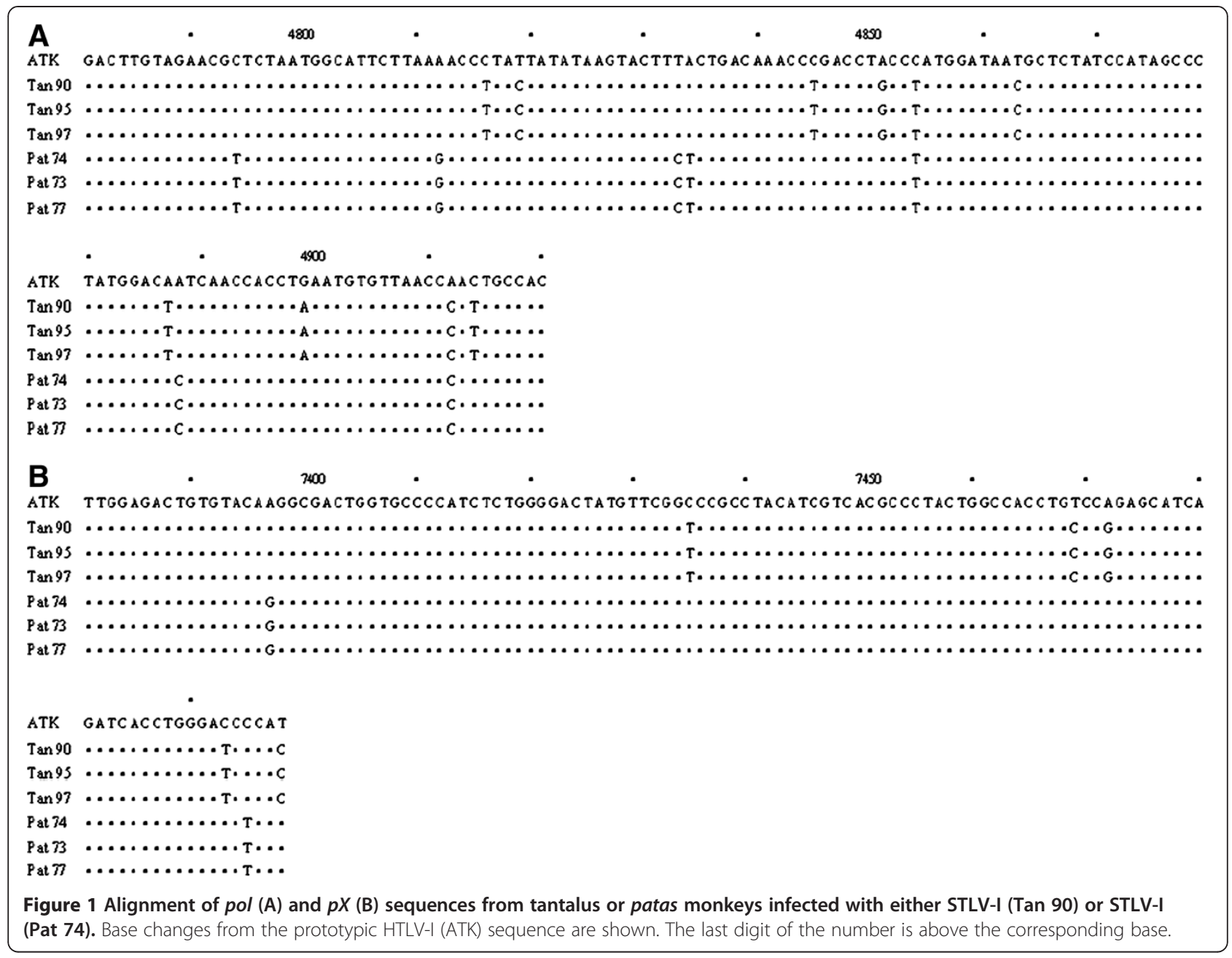

monkeys to become PCR positive for STLV-1 DNA in their peripheral blood mononuclear cell (PBMC) (Table 1). When they did become STLV-1 positive, it was at a lower copy number (10) than the patas monkeys (100); although by 12 months, all infected monkeys stabilized at a viral load of 100 copies of STLV-1 DNA/ $\mu$ g PBMC DNA.

We decided to completely sequence STLV-1 Tan 90 (GenBank accession \#AF074966), and partially sequence STLV-1 Pat 74 (GenBank accession \# L20354.1) to ascertain whether sequence differences could explain the different STLV-1 viral loads and seroconversion rates observed in the recipient tantalus and patas monkeys. The complete LTR DNA sequences and deduced individual protein amino acid sequences of STLV-1 Tan 90 relative to HTLV-1 ATK are shown in Additional file 1. The organization of the LTR of both viral strains is identical. Complete $U_{3}, R$, and $U_{5}$ regions are identified. Within these regions there are no major differences in the poly (A) signal, TATA box promoter, distal, and proximal $21 \mathrm{bp}$ enhancer regions, capsite, the sequences encoding the basic leucine zipper factor (bZ1P910), the
EtS protein binding domain, the splice donor site, the Rex core site, and the primer binding site (PBS). The STLV-1 Pat 74 LTR sequence was similarly arranged and conserved (data not shown). Both HTLV-1 ATK and STLV-1 Tan 90 contained the same number and locations of putative methylation sites, 5' to their promoters, but STLV-1 Pat 74 had two methylation sites (-291 and -60) altered from CpG to ApG which would render them methylase insensitive. Theoretically, this would make STLV-1 Pat 74 less susceptible to down modulation of viral RNA transcription by DNA methylation. Relative to HTLV-1 ATK, there were changes in both the STLV-1 Tan 90 and STLV-1 Pat 74 middle 21 bp repeat enhancer sequences. The former had a G-A transition outside of any consensus DNA protein binding domain, while the latter had an A-G transition in domain A (AP-2 consensus site). The effects of these changes are unknown. Throughout their genomes, consensus splice donor and splice acceptor sites found in HTLV-1 ATK were conserved in both STLV-1 Tan 90 and STLV-1 Pat 74 (data not shown). 


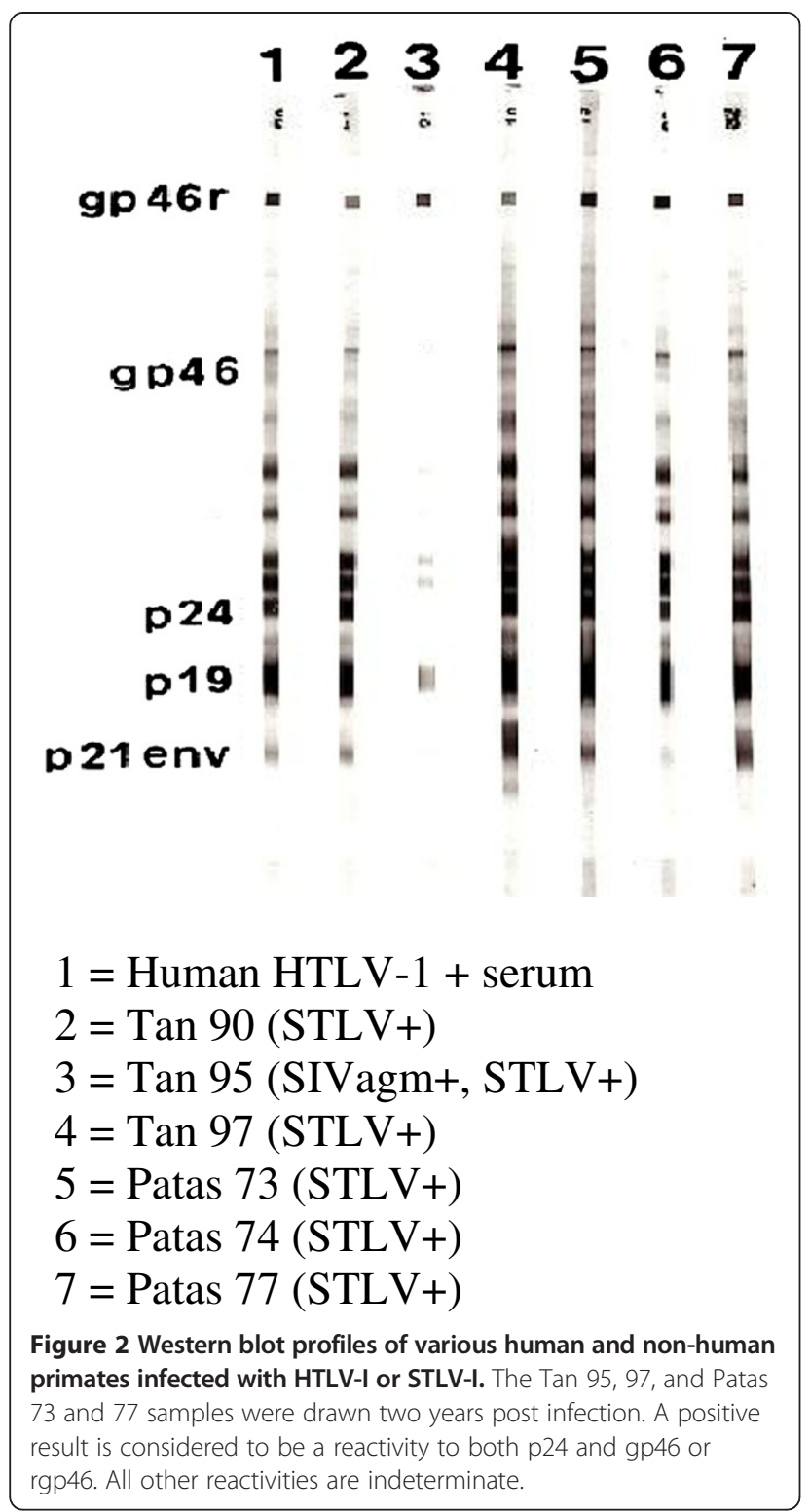

As can be seen (Additional file 1), there are minimal amino acid differences between the deduced prototypic HTLV-1 ATK and STLV-1 Tan 90 Gag, Protease, Env, Tax, p21 Rex and $\mathrm{P} 13^{\mathrm{II}}$ proteins. The stop codon in the ATK Pro is probably a sequencing error because this is not observed in any other PTLV-1 strain. It is difficult to know whether any of these minor changes could effect STLV-1 Tan 90 replication. There are greater amino acid differences in the $\mathrm{p} 30^{\mathrm{II}}$ and $\mathrm{p} 12^{\mathrm{I}}$ proteins, but again it is unclear how much this would affect their function. However, a $\mathrm{C}$ to $\mathrm{T}$ base substitution at position 2560 in the STLV-1 Tan 90 pol gene creates an early stop codon, and a deletion of an A at position 5140 in the pol gene eliminates a terminal stop codon present in the HTLV-1 ATK protein (Additional file 1 and Figure 4). This same deletion also causes an early frameshift in the p27 Rex protein, such that it is initially translated in the Tax reading frame, and then, because of splicing, results in a nonsense sequence (Additional file 1 and Figure 4). None of these changes are present in the STLV-1 Pat 74 sequence, nor in any other published PTLV-1 sequence (Additional file 1 and Figure 4). However, both mutations are present in the STLV-1 Tan 95 and 97 sequences (Additional file 1 and Figure 4), indicating that, while they may affect the replication rate of STLV-1 Tan 90, they did not prevent its transmission to other monkeys.

\section{Discussion}

Over presumably tens of thousands of years the PTLV have been disseminated among human and non-human primates throughout the planet. While phylogenetic data indicate that this dissemination has been predominantly intraspecies, evidence for episodic interspecies transmission exits as well [10,12-14]. It is unclear whether the replication rate or the pathogenicity of a particular substrain of the PTLV will be the same in all primates. In an effort to study the PTLV further, we established non-human primate models starting with the intraspecies transmission of two highly divergent isolates, STLV-1 Tan 90 and STLV-1 Pat 74. The data presented herein, indicate that successful infection can be achieved by transfusing whole blood from infected tantalus and patas monkeys to target animals of the same species. As anticipated, there was no evidence of genetic drift in the STLV-1 $p o l$ and $p X$ sequences analyzed between the original isolates and those found in the PBMC of the target animals. Also, none of the animals developed overt clinical disease during the 2-3 year followup period.

Interestingly, the Tan 95 and Tan 97 monkeys had prolonged seroconversion rates and different patterns compared to the Pat 73 and Pat 77 monkeys. It is doubtful that the PCR analyses, which confirmed infection in the tantalus monkeys, are false positives because they were performed three times and considerable effort was made to prevent and detect PCR "carryover". Also the STLV-1 sequences characterized in these two target monkeys are identical to the unique sequences of the STLV-1 Tan 90 strain with which they were inoculated. Finally, both monkeys eventually made antibodies to the HTLV-1 antigens utilized in the ELISA and Western blot assays, albeit Tan 95 never made detectable antibodies to the HTLV-I p24.

The diminished antibody response to the HTLV-I p24 antigen by Tan 95 could be explained if the STLV-1 Tan 90 isolate's p24 Gag antigen was highly divergent form prototype HTLV-1, but, in fact, it is not (Figure 3). This is consistent with the fact that the original tantalus monkey infected with STLV-1 Tan 90 was positive in both the ELISA and WB assays used herein $[9,10]$. Also, 


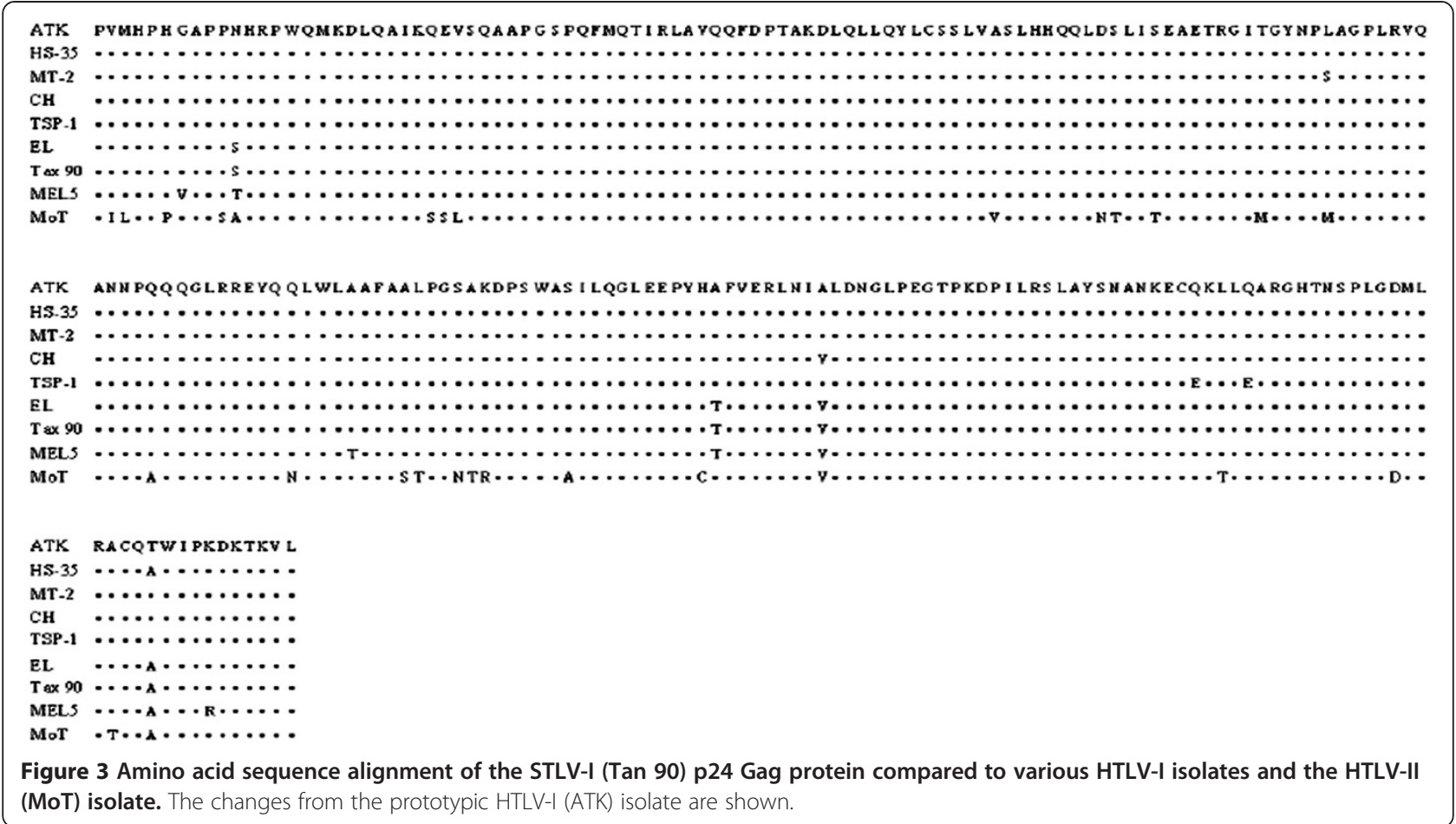

it has been well established that many conserved seroreactive epitopes exist among the PTLV and even bovine leukemia virus p24 Gag antigens [3,10-12,15,16].

It is doubtful that the difference between the seroconversion patterns between the tantalus and patas monkeys was due to quantitatively different innocula of STLV-1. However, the initial levels of STLV-1 DNA in the experimentally infected Tan 95 and Tan 97 monkeys were very low relative to those of the target patas monkeys, suggesting that a lower replication rate was the cause of the slower seroconversion.

It is difficult to say if the pre-existing SIV infection in Tan 95 had anything to do with its aberrant seroconversion. SIV is not felt to be pathogenic in African green monkeys and, by all analyses, Tan 95 was healthy and immunocompetent [17]. Delayed seroconversion to PTLV infection has been described before for both HTLV-1 and HTLV-2 naturally infected humans, and STLV-1 naturally infected non-human primates $[3,4,10]$. This phenomenon probably has more to do with the rate and pattern of PTLV protein expression than with the immune status of the host. Possible explanations for the inefficient expression of HTLV-1 proteins have included the presence of defective proviral DNA, the low rate of production of singly spliced and unspliced viral mRNA and the presence of natural antisense viral RNA [13,18]. While other changes such as differences in LTR methylation sites and the middle $21 \mathrm{bp}$ enhancer sequence may play a role, it would seem most likely that the stop codon mutation in the pol gene found in STLV-1 Tan 90 is a major reason for the slow seroconversion rates observed in Tan 95 and Tan 97. The fact that STLV-1 Tan 90 was transmitted to both Tan 95 and Tan 97 indicates that this mutation is not lethal. However, it would presumably require either one or more molecular events, such as read through termination suppression or using a downstream AUG translational start site, for functional STLV-1 Tan 90 Pol proteins to be produced [19]. Such a downstream start site is present not too far from the amino terminus of STLV-1 Tan 90 pol RNA (Additional file 1) While the predicted large Pol protein, due to the deletion at position 5140, might still produce a functional integrase protein, it is possible that proteolytic activity could cleave it into a smaller molecule [20].

The changes observed in the p27 Rex protein of STLV-1 Tan 90 would seemingly render it non-functional. Because Rex regulates expression of unspliced PTLV-1 RNAs, it would seem obvious that the STLV-1 Tan 90 would replicate more slowly in the host relative to other published PTLV strains, including STLV-1 Pat 74 [21]. In particular, a non-functional p27 Rex protein would result in less Gag p24 expression. Our data would indicate that a fully functional p27 Rex protein is not absolutely required for in vivo STLV-1 transmission. Whether p21 Rex could partially replace p27 Rex is unclear, but certainly possible; although it localizes to the cytoplasm rather than the nucleus [22,23]. Another possible "rescue" mechanism for translation of the STLV-1 Tan 90 p27 Rex protein could 


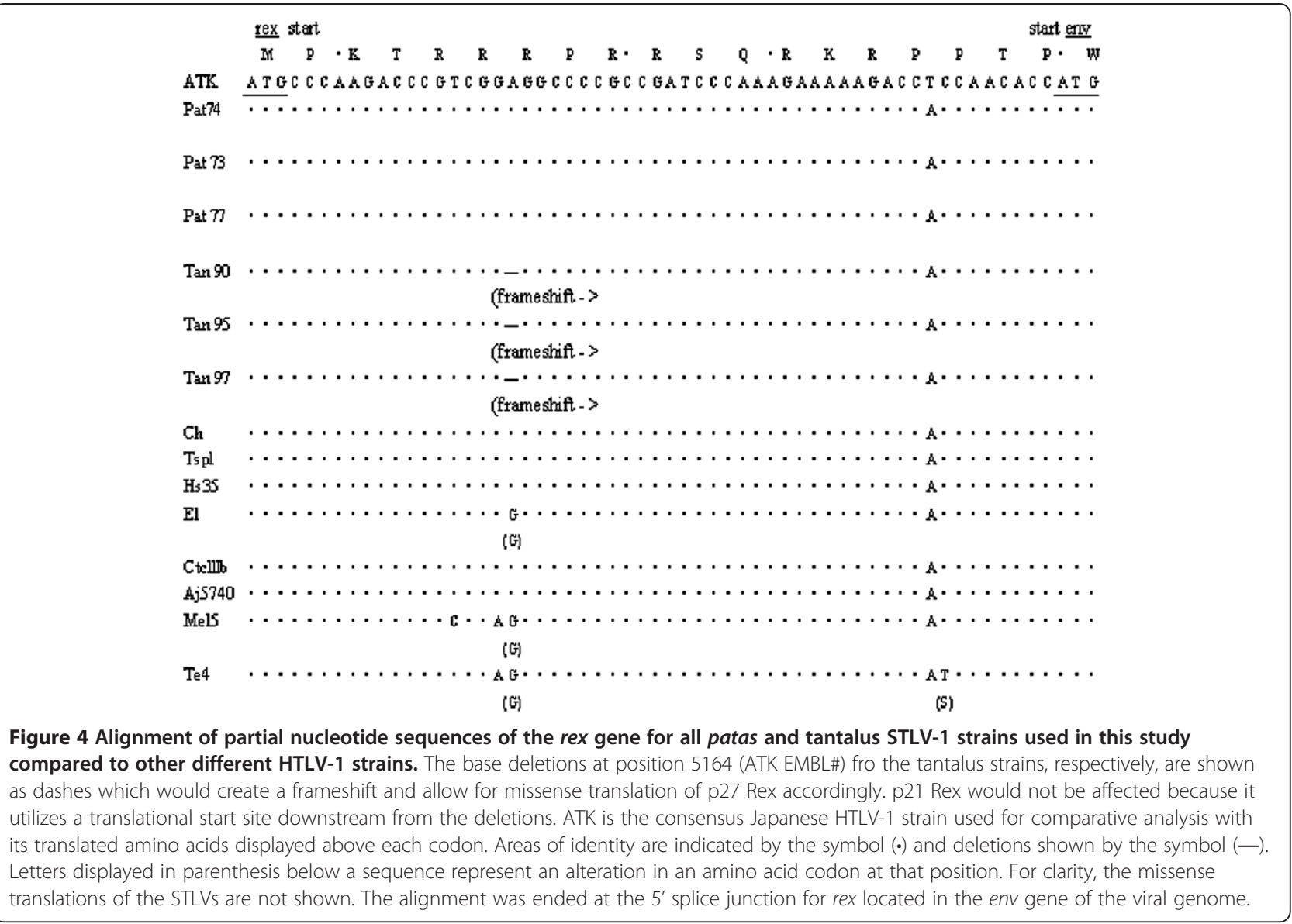

be a ribosomal frameshift $[24,25]$. Retroviral frameshifting usually occurs on an slippery heptanucleotide of the form XXXYYYZ. Two tRNAs bound to nucleotides 2 to 7 of this site simultaneously slip 1 to 2 bases leftward onto nucleotides 1 to 6 stimulated in part by a secondary structure in the downstream mRNA molecule called a pseudoknot. While the STLV-1 Tan 90 Rex RNA sequence does not have a "slippery" heptanucleotide at the site of the initial frameshift mutation, it does have a CCCAAAG heptanucleotide not too far downstream (Figure 4). There is also an alternative splice site just downstream from the deletion in the STLV-1 Tan $90 \mathrm{pol} / \mathrm{rex}$ genes. If utilized, instead of the routine splice site, an in-frame p27 Rex protein with a variable amino terminus would be produced.

An interesting question is how frequent the mutations observed in STLV-1 Tan 90 occur in other wild-type PTLV-1 strains and what their clinical implications might be. While it might seem intuitive that a slower replicating PTLV-1 strain might be less oncogenic, others have postulated that repression of virus expression, particularly by $\mathrm{p} 30^{\mathrm{II}}$, might allow for evasion of immunodestruction of virus infected cells and a higher probability of T-lymphocytic transformation [26]. Further, epidemiological studies would seem warranted to answer the above questions.

\section{Methods}

Animal trapping, infection and sampling

Wild $C$. tantalus and $E$. patas monkeys were captured in Central African Republic. Approval for collecting simian specimens was granted by the Comité Consultatif D'Ethique en Experimtation Animale (C.C.E.E.A.) de l'Ecole Inter-Etats des Sciences et Medicine Veterinaires de Dakur. As previously described, two of these monkeys, Tan 90 and Pat 74, were found to be infected with the unique STLV-1 strains Tan 90 and Pat 74 [9,10], respectively. Two tantalus monkeys (Tan 95 and 97) and 2 patas monkeys (Pat 73 and 77 ) were found to be consistently negative for STLV-1 by serological, PCR and virus culture analyses [10]. One of these monkeys, Tan 95, was found to be infected with the simian immunodeficiency virus (SIV) [17]. All of the monkeys were deemed to be healthy without signs of leukemia nor immunodeficiency. All had normal CD4 counts (range $660-1200 / \mathrm{mm}^{3}$ ), CD8 counts (range 100-500 cells $/ \mathrm{mm}^{2}$ ), and immunoglobulin levels (eg IgG range 1000$3000 \mathrm{mg} / \mathrm{dL}$ ). These animals were tested for STLV three 
times in the months prior to inoculation including the day of inoculation.

Three $\mathrm{ml}$ of whole blood collected in EDTA from Tan 90 were transfused into both Tan 95 and Tan 97, and an equivalent amount of whole blood from Pat 74 was transfused into Pat 73 and Pat 77. Quantitative DNA PCR indicated that the STLV-1 viral load in these inocula were approximately the same (100 copies of STLV1 DNA per $\mu \mathrm{g}$ of primate DNA). The experimentally and naturally infected monkeys were monitored for an additional two years with routine physical exams, examination of their complete blood count, differential CD4 and CD8 counts, and immunoglobulin levels. Periodically, aliquots of their heparinized whole blood were separated into plasma and PBMC and examined for STLV-1 antibodies and DNA, respectively.

\section{Serological assays}

Plasma were analyzed using an HTLV-1 whole viral antigen ELISA (Diagnostic Biotechnology Singapore) and a Western blot kit (Diagnostic Biotechnology), which in addition to HTLV-1 whole viral antigens, also includes recombinant HTLV-1 rgp21 and rgp46 Env peptides [11]. US Public Health criteria were used to designate a serologic result as positive, negative or indertminate [27].

\section{PCR}

One $\mu \mathrm{g}$ of organically extracted DNA from the monkey PBMC was amplified and detected via PCR using the PTLV 1/2 generic pol (SK110/SK111) and tax (SK43/ SK44) primers, and the HTLV-1/STLV-1 specific detector SK112 and the PTLV $1 / 2$ generic detector SK45, as previously described [12]. All samples were also analyzed for primate $\beta$-globin DNA as previously described to assure that amplifiable DNA was present in the sample [12]. All PCR assays were done in triplicate. In order to avoid false positives due to "carryover" of previously amplified DNA, all pre- and post- PCR steps were conducted in completely different facilities by different personnel. In addition, all amplifications of the above regions done in our laboratory utilize dUTP rather than TTP, and all amplifications were subjected to PCR sterilization with uracil glycosylase [28]. Finally, all primers contain 5' non-viral non-primate linker sequences, which, in addition to facilitating the cloning of amplified DNA (see below), allow for the use of "signature primers" for the detection of "carryover"

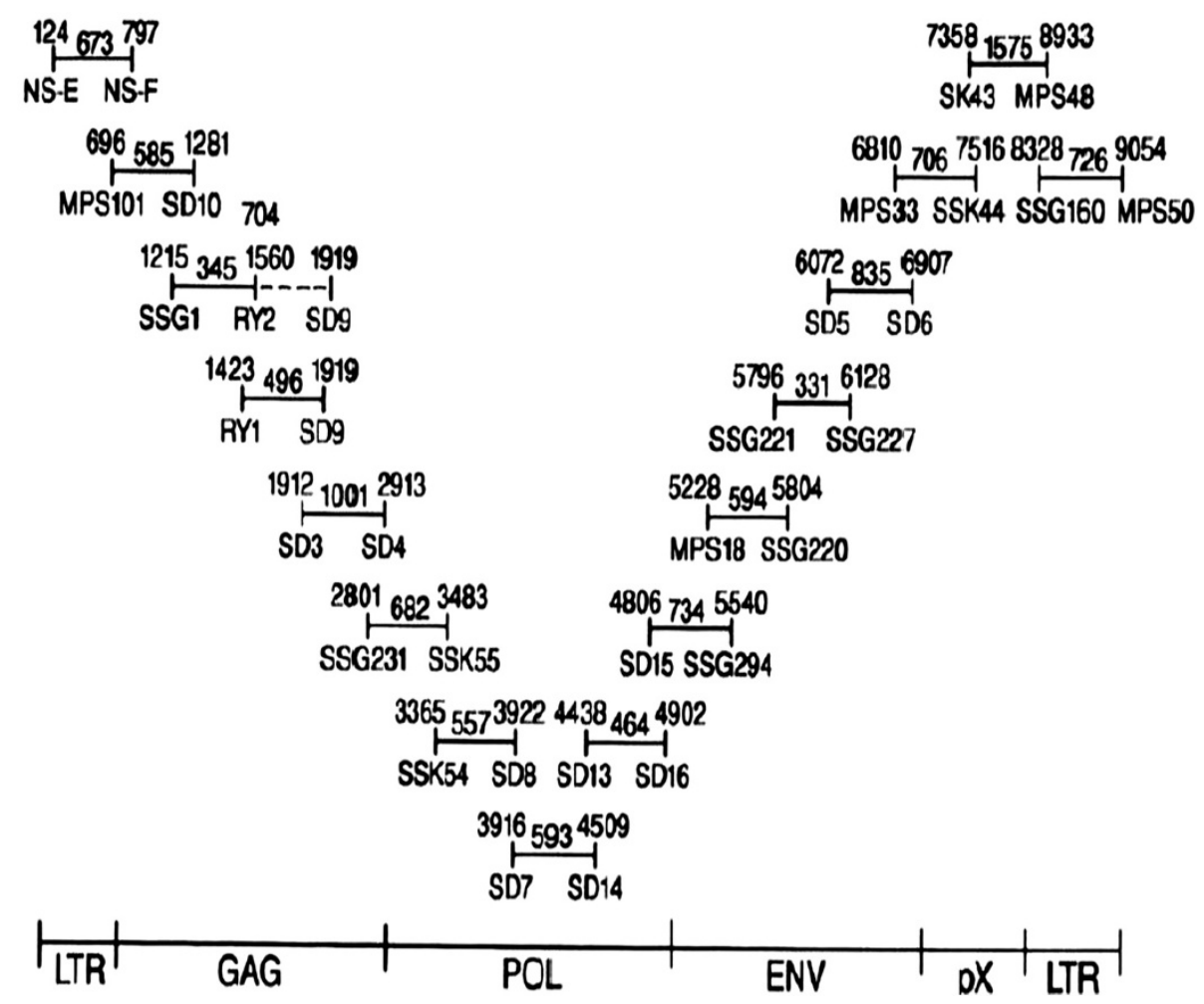

Figure 5 Schematic representation of overlapping PCR primer pairs utilized to amplify the entire STLV-1 genome of strain Tan 90 . The numbers above the primer notations are according to their position in the EMBL consensus HTLV-I sequence while the length of the fragment contributed by each primer pair is shown in between. The DNA amplicons produced were cloned and sequenced to further investigate the molecular identity of STLV-I Tan 90. 
DNA. Accordingly, all STLV-1 PCR positive samples were reanalyzed with "signature primers" and found to be negative for "carryover" DNA [29]. Quantification was estimated by comparison of hybridization signals to a serially diluted positive control, and also by serially diluting the input DNA sample and calculation of the Poisson distribution in the original sample. This assay is $100 \%$ and $58 \%$ sensitive down to concentrations of 10 copies and 1 copy per aliquot, respectively.

To examine the gag p24 (bases 1214-1855 as per the EMBL numbering system) region of the STLV-1 strains, the following overlapping primers were utilized: HTIL (715-734) + (TACTGGCTCGGAGCCAG CAG); HTIG (1499-1479) - (GACCGGCTAAGGGG TTATAAC); HTIG (1423-1444) + (CCATCACCAGCA GCTAGATAGC); AND HTIG (1919-1899) - (AGTG GCCTGCTTTCCCGCACC). The probe utilized was HTIG (1475-1507) + d (ACAGGTTATAACCCATTAGCC GGTCCCCTCCGT). The bases are all listed 5' to 3'.

\section{Cloning and sequencing}

Cloning of the $p 24$, pol and $p X$ PCR amplified products, listed above, was accomplished by digesting the DNA with Kpn I and SstI, and subsequent ligation into M13mp18. The ligation mixes were used to transfect competent KT8052 (ung-) E. Coli cells plated with media containing 5-bromo-4chloro-33indolyl B-D galactoside and isopropyl B-D thiogalactoside $[10,30]$. Positive clones were detected by plaque hybridization with the appropriate specific oligonucleotide probe (see above) and the DNA from the positive plaques was sequenced by the dideoxynucleotide chain termination method [31]. The full length sequence of STLV-1 Tan 90 and the partial sequence of STLV-1 Pat 74 were derived using a series of overlapping PCR primers, probes, cloning and sequencing, as previously described (Figure 5) [9]. Sequencing was performed in both directions and all major changes were verified in at least five clones.

Nucleotide sequence alignments were generated using a commercial software package [32].

\section{Additional file}

Additional file 1: Nucleic acid (LTR) and amino acid sequences of HTLV-1 ATK and STLV-1 Tan 90. Areas of homology are indicated by the symbol $(\cdot)$, deletions by $(-)$ and stop codons by $\left(^{*}\right)$. The various base or amino acid substitutions are as indicated. In the LTR the junctions between $\mathrm{U} 3, \mathrm{R}$ and $\mathrm{U} 5$ are shown, the three 21 bp repeat enhancer sequences are underlined, the primer binding site (PBS) is overlined. The basic leucine zipper factor (bZ1P910), poly A signal, TATA box promoter (AP site, splice donor (SD) and rex core sites are labeled. Functional areas of the PTLV-1 Tax primer are identified.

\section{Competing interests}

The authors declare that they have no competing interests.

\section{Authors' contributions}

SD, NS, TS, JH, and PB participated in molecular studies. NS was involved in the serologic studies. SD, DD and BP participated in the sequence alignment and analysis. NS and BP conceived of the study. NS, SD, DD and BP

participated in the design and coordination of the study and drafting of the manuscript. All authors read and approved the final manuscript.

\section{Acknowledgments}

We are grateful to Kat Trouesdale for manuscript preparation, and the staff members at the Pasteur Institute, Bangui, CAR, who participated in the capture of the monkeys. This work was supported by PHS grants R01-HL-43602-01, and 5-V01-Al-27658, and the Barbara Kopp Cancer Research Fund.

\section{Sequence data}

GenBank: AF074966.1; L20354.1

\section{Author details}

'Division of Hematology/Oncology, Department of Medicine, State University of New York, Upstate Medical University, 750 East Adams Street, Syracuse, NY 13210, USA. ${ }^{2}$ Retroviral Genetics Division, Center for Virus Research, Westmead Millennium Institute, University of Sydney, Westmead NSW 2145, Sydney, Australia.

Received: 24 May 2013 Accepted: 28 August 2013

Published: 11 September 2013

\section{References}

1. Sintasath $\mathrm{DM}$, Wolfe $\mathrm{ND}$, Zheng $\mathrm{HQ}$, et al: Genetic characterization of the complete genome of a highly divergent simian T lymphotropic (STLV) type 3 from a wild Cercopithecas mona monkey. Retrovirology 2009, 6:97. doi:10.1186/1742-4690-6-97.

2. Sintasath $\mathrm{DM}$, Wolfe ND, Lebreton $\mathrm{M}$, et al: Simian T-lymphotropic virus diversity among nonhuman primates, Cameroon. Emerg Infect Dis 2009, 15:175-184.

3. Ehrlich GD, Glaser JB, Abbott MA, Slamon DJ, Kuth D, Sliwkouski M, Brandis J, Keitelman E, Teramoto Y, Papsidero L, Simpkins H, Sninsky JJ, Poiesz BJ: Dection of anti-HTLV-I Tax antibodies in HTLV-I enzyme-linked immunosorbent assay-negative individuals. Blood 1989, 74:1066-1072.

4. Ehrlich GD, Glaser JB, La Vigne K, Quan D, Mildvan D, Sninsky JJ, Kwok S, Padsidero L, Poiesz BJ: Prevalence of human T-cell leukemia/lymphoma virus (HTLV) type II infection among high-risk individuals: type-specific identification of HTLVs by polymerase chain reaction. Blood 1989, 74:1658-1664

5. Poiesz BJ, Poiesz MJ, Choi DJ: The human T-cell lymphoma/leukemia viruses. Cancer Invest 2003, 21:253-277.

6. Sakaibara I, Sugimoto Y, Sasagawa A, Honjo S, Tsujimoto H, Nakamura H, Hayami M: Spontaneous malignant lymphoma in a African green monkey naturally infected with simian lymphotropic virus (STLV). J Med Primatol 1986, 15:311-318.

7. Noda Y, Ishikawa A, Sasagawa S, Honjo S, Mori S, Tsujimoto H, Hayauri M: Hematologic abnormalities in African green monkeys infected with Simian T-cell leukemia virus. Japan J Cancer Res. 1986, 77:1227-1232.

8. Tsujimoto H, Noda Y, Ishikaw K, Nakamura H, Fukasawa M, Sakakibara I, Sasagawa A, Honjo S, Hajuri M: Development of adult T-cell leukemia-like disease in African green monkey associated with clonal intergration of Simian T-cell leukemia virus I. Cancer Res 1987, 147:269-274.

9. Saksena NK, Herve V, Sherman MP, Durand JP, Mathiot C, Muller M, Love JL, Barre'-Sinoussi FB, Dube DK, Poiesz BJ: Sequence and phylogenetic analysis of a new STLV-I from a naturally infected Tantalus monkey from Central Africa. Virology 1993, 192:312-332.

10. Saksena NK, Herve V, Durand JP, Leguenno B, Diop OM, Digoutte JP, Mathiot C, Muller M, Love JL, Dube S, Sherman MP, Benz PM, Erensoy S, Galat-Luong A, Galat G, Paul B, Dube DK, Barre'-Sinoussi F, Poiesz BJ: Seroepidemiologic, molecular and phylogenetic analyses of simian T-cell leukemia viruses (STLV-I) from various naturally infected monkey species from Central and Western Africa. Virology 1994, 198:297-310.

11. Lipka JJ, Miyoshi I, Hadlock KG, Reyes GR, Chow TP, Blattner WA, Shaw GM, Hanson CV, Gallo D, Chan L, Foung SKH: Segregation of human T cell lymphotropic virus type I and II infections by antibody reactivity to unique viral epitopes. J Infect Dis 1992, 165:268-272. 
12. Dube DK, Dube S, Erensoy $S$, Jones B, Bryz-Gornia V, Spicer T, Love J, Saksena N, Lechat MF, Shrager DI, Dosik H, Glaser J, Levis W, Blattner W, Montagna R, Blumberg BS, Poiesz BJ: Serological and nucleic acid analyses for HIV and HTLV infection of archival human plasma samples from Zaire. Virol 1994, 202:379-389.

13. Poiesz BJ, Sherman M, Saksena N, Dube D, Sube S, Gavalchin J, Fan N, Lane M, Paul B: The biology and epidemiology of the human T-cell lymphoma/leukemia viruses. In Frontiers of Infectious Diseases. Focus on HIV. Edited by Neu HC, Levy J, Weiss R. London: Churchill Livingstone; 1993:189-205

14. Koralnik IJ, Boeri E, Saxinger WC, Monico AL, Fullen J, Gessain A, Guo H, Gallo RC, Markham P, Kalyanaraman V, Hirsch V, Allan J, Murthy K, Alford P, Slattery JP, O'Brien SJ, Franchini G: Phylogenetic associations of human and simian T-cell leukemia/lymphotropic virus type I strains: evidence for interspecies transmission. J Virol 1994, 68:2693-2707.

15. Watanabe T, Seiki M, Tsyjimoto H, Miyoshi I, Hayami M, Yoshida M: Sequence homology of the simian retrovirus genome with human T-cell leukemia virus type-I. Virology 1985, 144:59-65.

16. Zandomeni RO, Carrera-Zandomeni M, Esteban E, Ferrer JF: The trans-activating C-type retroviruses share a distinct epitope(s) that induces antibodies in certain infected hosts. J Gen Virol 1991, 72:2113-2119.

17. Muller MC, Saksena NK, Nerrienet E, Chappey C, Herve' VM, Durand JP, Legal-Campodonico P, Lang MC, Digoutte JP, Georges AJ, Georges-Courbot MC, Sonigo P, Barre'-Sinoussi F: Simian immunodeficiency viruses from central and western Africa: evidence for a new species-specific lentivirus in tantalus monkeys. J Virol 1993, 67:1227-1235

18. Dube S, Paul B, Bryz-Gornia V, Stephens C, Erensoy S, Dube DK, Poiesz BJ: Use of PCR in the detection of antisense transcripts in HTLV-I infected patients and human T-cell lines. In Methods in Neuroscience: $P C R$ in Neuroscience, Volume 26. Edited by Sarkar G. New York: Academic Press; 1995:39-44.

19. Swanstrom R, Wills JW: Synthesis assembly and processing of viral proteins. In Retroviruses. Edited by Coffin JM, Hughes SH, Varmus HE. New York: Cold Spring Harbor Press; 1997:263-334.

20. Mariani VL, Becham Shuker S: Identification of the RT-RH/IN cleavage site of HTLV-I. Biochem Biophys Res Com 2003, 300:268-270.

21. Inoue Jl, Yoshida M, Seiki M: Transcriptional $\left(\mathrm{p} 40^{\mathrm{x}}\right)$ and post-transcriptional (p27 $7^{\mathrm{X}}$-III) regulators are required for the expression and replication of human leukemia virus type I genes. Proc Natl Acad Sci USA 1987, 84:3653-3657.

22. Kiyokawa T, Seiki M, Iwashita S, Imagawa K, Shimizu F, Yoshida M: p27x III and $\mathrm{p} 21 \mathrm{x}^{\mathrm{III}}$ proteins encoded by the px sequence of human T-cel leukemia virus type I. Proc Natl Acad Sci U S A 1985, 82:8356-8363.

23. Yoshida M, Suzuki T, Fujiswasa J, Hirai H: HTLV-1 oncoprotein tax and cellular transcription factors. Curr Top Microbiol Immunol 1995:79-89.

24. Hu PY, Waheed A, Sly W: Partial rescue of human carbonic anhydrase II frameshift mutation by ribosomal frameshift. Proc Natl Acad Sci USA 1995, 92:2136-2140

25. Farbough P: Alternative readings of the genetic code. Cell 1993, 74:591-596.

26. Younis I, Khair L, Dundr M, Lairmore MD, Franchini G, Green P: Repression of human T-cell leukemia virus type 1 and 2 replication by a viral mRNA-encoded posttranscriptional regulator. J Virol 2004 78:11077-11083.

27. Anderson DW, Epstein JS, Pierick LT, Lee TH, Lairmore MD, Saxinger C, Kabyanaraman VS, Slamon D, Parks W, Poiesz BJ, Blattner W: Development of the Public Health Service criteria for serological confirmation of HTLV-I/II infections. In Human Retrovirolgy. Edited by Blattner W. New York Raven Press; 1990:391-396

28. Longo MC, Beringer MS, Hartley JL: Use of Uracil DNA glycosylase to control carryover contamination in polymerase chain reaction. Gene 1990, 93:125-128.

29. Abbott LZ, Spicer T, Bryz-Gornia V, Kwok S, Sninsky J, Poiesz B: Design and use of signature primers to detect carry-over of amplified material. $J$ Virol Meth 1994, 46:51-59.
30. Kunkel TA, Roberts JD, Zakow RA: Rapid and efficient site-specific mutagenesis without phenotype selection. Methods Enzymol 1987, 154:367-382.

31. Sanger F, Nicklen S, Coulson AR: DNA sequencing with chain-terminating inhibitors. Proc Natl Acad Sci U S A 1977, 74:5463-5467.

32. DevereauX J, Haeberli $P$, Smithies O: A comprehensive set of sequence analysis programs for VAX. Nucleic Acids Res 1984, 12:387-395.

doi:10.1186/1743-422X-10-282

Cite this article as: Dube et al:: Delayed seroconversion to STLV-1

infection is associated with mutations in the pol and rex genes. Virology Journal 2013 10:282.

\section{Submit your next manuscript to BioMed Central and take full advantage of:}

- Convenient online submission

- Thorough peer review

- No space constraints or color figure charges

- Immediate publication on acceptance

- Inclusion in PubMed, CAS, Scopus and Google Scholar

- Research which is freely available for redistribution

Submit your manuscript at www.biomedcentral.com/submit
C Biomed Central 